\title{
Gambaran Kualitas Tidur Yang Terjadi Pada Lansia Di Panti Sosial Tresna Werdha Nirwana Puri Samarinda Pada Era Pandemi Covid-19
}

\author{
Heri Saputra ${ }^{1}$, Marina Kristi Layun ${ }^{2}$, Rusdi $^{3}$, Anisa Ain ${ }^{4}$ \\ ${ }^{1}$ Program Studi Ilmu Keperawatan, ITKES Wiyata Husada Samarinda \\ Jl. Kadrie Oneing No.77, Samarinda, Kalimantan Timur \\ herrysaputra31@gmail.com \\ ${ }^{2}$ Program Studi Ilmu Keperawatan, ITKES Wiyata Husada Samarinda \\ Jl. Kadrie Oneing No.77, Samarinda, Kalimantan Timur \\ marinalayun@,itkeswhs.ac.id \\ ${ }^{3}$ Program Studi Ilmu Keperawatan, ITKES Wiyata Husada Samarinda \\ Jl. Kadrie Oneing No.77, Samarinda, Kalimantan Timur \\ rusdi@itikeswhs.ac.id \\ ${ }^{4}$ Program Studi Ilmu Keperawatan, ITKES Wiyata Husada Samarinda \\ Jl. Kadrie Oneing No.77, Samarinda, Kalimantan Timur \\ anisaain@itikeswhs.ac.id
}

\begin{abstract}
ABSTRAK
Latar belakang : Tidur merupakan salah satu kebutuhan dasar manusia. Kualitas tidur dapat menjadi salah satu indikator dalam menentukan kualitas hidup seseorang, terutama pada lansia. Tujuan : Dari penelitian ini adalah untuk mengetahui gambaran kualitas tidur yang terjadi pada lansia berdasarkan variabel usia, jenis kelamin, dan status perkawinan. Metode : Penelitian ini merupakan penelitian kuantitatif dengan menggunakan rancangan cross-sectional. Teknik sampling yang digunakan adalah consecutive sampling dengan jumlah sampel 71 responden. Hasil penelitian : Data demografi berdasarkan umur dalam rentang dengan jumlah 75-89 tahun (71.4\%) dan 6074 tahun $(28.6 \%)$, berdasarkan jenis kelamin ditemukan perempuan (52.4\%) dan laki-laki (47.6\%), berdasarkan status perkawinan dengan status janda/duda (81,0\%) dan berstatus menikah (19.0\%). Kesimpulan : Lansia di panti menunjukan ada gambaran yang bermakna antara karakteristik responden dengan kualitas tidur lansia dimana semakin tinggi skor kualitas tidur selama era pandemi covid-19 maka akan semakin buruk kualitas tidur.
\end{abstract}

Kata kunci : Lansia, Kualitas tidur, Covid-19

\section{PENDAHULUAN}

Menua merupakan proses alami yang akan dialami seluruh manusia. Menua merupakan tahap akhir dari kehidupan manusia. Kemunduran Fisiologis dan mental pada seorang lansia akan menghambat berlangsungnya aktivitas kehidupan keseharian lansia. Berkurangnya kemampuan fisik dan mental ini juga dapat mengakibatkan ketidakmampuan dalam melaksanakan peranan hidup secara normal (Raveena, 2017). Penuaan merupakan sebuah proses yang terjadi secara alami dan tidak dapat 
dihindari oleh semua orang. Sekarang banyak yang bertahan dari perkembangan untuk hidup lebih lama mencapai umur yang panjang. (World Health Organization, 2012).

Secara global, Asia dan Indonesia dari tahun 2015 sudah memasuki era penduduk menua (ageing population) karena jumlah penduduknya yang berusia 60 tahun ke atas (penduduk lansia) melebihi angka 7 persen. (Pusat Data dan Informasi Kemenkes RI, 2015). Kota Samarinda yang merupakan ibukota dari Provinsi Kalimantan Timur juga mengalami peningkatan jumlah lansia tiga tahun terakhir yaitu tahun 2015 terdapat 34.112 jiwa $(4,6 \%)$ dari 741.554 jiwa, tahun 2016 menjadi 39.715 jiwa (5,3\%) dari 749.340 jiwa dan tahun 2017 menjadi 46.947 jiwa $(6,2 \%)$ dari 757.208 jiwa. Akan tetapi jumlah lansia dibina mengalami penurunan yaitu tahun 2015 sebesar 30\%, tahun 2016 menjadi 28\% dan tahun 2017 hanya mencapai 25\% (Dinas Kesehatan Kota Samarinda, 2017).

Dalam masa pandemi COVID-19 ini, lansia menjadi kelompok masyarakat yang paling rentan dan memiliki resiko paling tinggi dibandingkan yang lainnya. Hal ini dibuktikan dengan tingginya korban meninggal pada lansia. Data dari WHO menunjukkan angka kematian paling tinggi terjadi pada penderita COVID-19 yang berusia 80 tahun ke atas dengan persentase mencapai lebih dari $22 \%$ (Wisnubrata, 2020). Lembaga kesehatan masyarakat Amerika Serikat (CDC) juga menjelaskan bahwa kematian terbesar akibat COVID-19 ini adalah kelompok umur 65 tahun keatas dan lebih dari 60\% per 20 Mei 2020 (Central Disease Control and Prevention, 2020). Sedangkan untuk Indonesia, berdasarkan data dari satuan tugas penanganan COVID-19, kelompok umur yang meninggal dunia paling tinggi berada di kelompok umur $>60$ tahun (lansia) yaitu sebanyak 44\%, sedangkan untuk kelompok umur 46-59 tahun sebanyak 40\%, dan pada umur 31-45 tahun sebanyak $11,6 \%$.

Peningkatan populasi lansia tersebut merupakan dampak dari adanya peningkatan usia harapan hidup penduduk, peningkatan usia harapan hidup terjadi di negara maju maupun di negara berkembang termasuk Indonesia. Orang lanjut usia memiliki jumlah jam tidur yang agak lebih singkat atau sama dengan orang dewasa, namun waktu tidur mereka lebih sering terputus secara spontan, selain itu mereka membutuhkan waktu lebih lama untuk dapat kembali tidur setelah terbangun. Dengan demikian, orang lanjut usia secara umum memiliki waktu tidur yang lebih sedikit dalam kaitan dengan total waktu yang mereka habiskan ditempat tidur pada malam hari, mereka cenderung mengganti kekurangan 
waktu tidur tersebut dengan tidur siang (Araujo \& Ceolim, 2010).

Gangguan tidur pada lanjut usia sendiri cukup tinggi, hasil dari National Sleep Foundation di Amerika sekitar 67\% dari 1.508 lanjut usia mengeluhkan gangguan kualitas tidur dan 7,3\% lanjut usia mengeluhkan gangguan memulai dan mempertahankan tidur atau insomnia (Rahmah, Retnaningsih, \& Apriana, 2018). Kelompok lanjut usia lebih banyak mengeluh terbangun lebih awal dari pukul 05.00 pagi, selain itu terdapat $30 \%$ kelompok usia 70 tahun yang banyak terbangun di waktu malam hari. Angka ini ternyata 7 kali lebih besar dibandingkan dengan kelompok usia 20 tahun. Pada kelompok lanjut usia (40 tahun) hanya dijumpai 7\% yang mengeluh masalah tidur (hanya dapat tidur tidak lebih dari 5 jam sehari). Hal yang sama dijumpai pada $22 \%$ kasus pada kelompok 70 tahun Stuart dan Sundeen dalam Priyoto (2015). Di Indonesia sendiri gangguan kualitas tidur menyerang $50 \%$ lanjut usia yang berusia 60 tahun keatas, $30-40 \%$ gangguan tidur yang sering ditemukan pada lanjut usia adalah insomnia (Rahmah, Retnaningsih, \& Apriana, 2018).

Masalah tidur yang sering dialami pada lanjut usia adalah sering terjaga pada malam hari, sering kali terbangun pada dini hari, rasa lelah yang amat sangat pada siang hari, dan sulit untuk tertidur Davison dalam Dariah \& Okatiranti (2015). Selain itu perubahan tidur juga sering terjadi pada lanjut usia yang mengalami depresi (Ouyang \& Sun, 2018).

Berdasarkan studi pendahuluan yang dilakukan pada tanggal 18 April 2020 melalui staf Panti Tresna Werdha Nirwana Puri Samarinda diketahui jumlah lansia yang berada di panti sosial Panti Tresna Werdha Nirwana Puri Samarinda sebanyak 101 orang, yang terdiri dari lansia pria sebanyak 51 orang dan lansia wanita sebanyak 50 orang. Hasil dari pengkajian kualitas tidur menggunakan kuesioner PSQI (Pittburgh Sleep Quality Index), dari 101 orang diperoleh sebanyak 15 orang lansia tersebut mengatakan yang mempengaruhi tidurnya 1 lansia mengatakan karena mengalami nyeri sendi, 2 orang lansia mengatakan sering merasakan BAK pada saat tidur, 2 orang lansia mengatakan cemas dan merasa bingung, 4 orang lansia mengatakan terbangun karena suara ribut atau kebisingan, 3 orang lansia mengatakan karena cuaca panas saat malam hari, 2 orang lansia mengatakan sering minum kopi, 1 orang lansia mengatakan sering merokok. 
Berdasarkan uraian diatas, maka peneliti merasa tertarik untuk melakukan penelitian mengenai "gambaran kualitas tidur yang terjadi pada lansia di panti sosial tresna werda nirwana puri samarinda pada era covid-19"

\section{METODE PENELITIAN}

Jenis penelitian ini adalah penelitian kuantitatif. Rancangan penelitian yang dipilih adalah deskriptif pengertian dari suatu metode yang berfungsi untuk mendeskripsikan atau memberi gambaran objek yang diteliti melalui data atau sampel yang telah terkumpul sebagaimana adanya tanpa melakukan analisis dan membuat kesimpulan yang berlaku untuk umum (Sugiyono, 2016). Dengan menggunakan desain penelitian cross sectional yaitu dimana suatu peneliti menekankan pada pengukuran atau observasi data pada satu waktu untuk mengetahui "gambaran kualitas tidur yang terjadi pada lansia di panti sosial tresna werdha nirwana puri samarinda pada era pandemi covid-19"

\section{HASIL ANALISIS UNIVARIAT}

\section{Gambaran Karakteristik Responden}

Data hasil penelitian dari kuisioner yang telah disebarkan kepada lansia melalui perantara pengasuh lansia pada bulan Juli 2020 di Panti Sosial Tresna Werdha Nirwana Puri Samarinda diolah secara komputerisasi menggunakan program SPSS versi
21.0. Lansia yang memenuhi kriteria inklusi penelitian dan dimasukkan kedalam sampel sebanyak 63 orang.

Dari pengolahan data statistik deskriptif diperoleh data yaitu sebagian besar lansia berumur 75-90 tahun $(71,4 \%)$, dengan persentase jenis kelamin antara laki-laki dan perempuan memiliki sebaran yang hampir merata $(47,6 \%$ dan $52,4 \%$ secara berurutan). Berdasarkan variabel status perkawinan, didapatkan data bahwa lebih dari setengah sampel berada dalam status janda/duda (81,0\%). Pada penelitian ditemukan sebagian besar lansia memiliki kualitas tidur yang buruk (68.3\%) (Tabel 4.1)

Tabel 4.1 Karakteristik Responden

\begin{tabular}{clrc}
\hline No & Karakteristik & F & P (\%) \\
\hline 1. & Usia $(\mathrm{n}=63)$ & & \\
& $(60-74)$ & 18 & 28,6 \\
& $(75-90)$ & 45 & 71,4 \\
\hline 2. & Jenis & & \\
& Kelamin(n=63) & 30 & 47,6 \\
& Laki-laki & 33 & 52,4 \\
& Perempuan & & \\
\hline 3. & Status Perkawinan & & \\
& (n=63) & & \\
& Menikah & 12 & 19,0 \\
& Janda/duda & 51 & 81,0 \\
\hline
\end{tabular}

Sumber : Data Sekunder, 2020

\section{Komponen kualitas tidur}

Hasil pengumpulan data berkaitan dengan frekuensi pilihanjawaban responden tentang komponen kualitas tidur lanjut usia di PSTW Nirwana 
Puri Samarinda Tahun 2020.

Berdasarkan ketujuh komponen kualitas tidurpada kuesioner PSQI adalah sebagai berikut :

Tabel 4.2. Distribusi frekuensi pilihan jawaban responden tentang komponen kualitas tidur

\begin{tabular}{lc}
\hline Kualitas Tidur & Frekuensi \\
\hline Kualitas tidur subyektif & \\
\hline Sangat baik & 1 \\
Baik & 46 \\
Kurang & 8 \\
Sangat kurang & 8 \\
\hline Latensi tidur & \\
\hline Sangat baik & 21 \\
Baik & 28 \\
Kurang & 14 \\
Sangat kurang & 0 \\
\hline Durasi tidur & \\
\hline Sangat baik & 47 \\
Baik & 9 \\
Kurang & 6 \\
Sangat kurang & 1 \\
\hline Efisiensi tidur & \\
\hline Sangat efisien & 57 \\
Efisien & 0 \\
Kurang efisien & 0 \\
Tidak efisien & 6 \\
\hline Gangguan tidur & \\
\hline Tidak gangguan tidur & 0 \\
Gangguan tidur ringan & 39 \\
Gangguan tidur sedang & 23 \\
Gangguan tidur berat & 0 \\
\hline Penggunaan obat tidur & \\
\hline Tidak pernah & 2 \\
Sekali seminggu & 18 \\
2 kali seminggu & 32 \\
3 kali seminggu & 11 \\
\hline Disfungsi siang hari & \\
\hline Tidak pernah & 12 \\
Masalah kecil & 33 \\
Masalah sedang & \\
Masalah berat & \\
\hline Sumber Data Sekunder, 2020 & \\
\hline
\end{tabular}

\section{Data Skor Pittsburgh Severity Quality Index (PSQI)}

Tabel 4.3 Distribusi frekuensi data skor Pittsburgh Severity Quality Index (PSQI)

\begin{tabular}{llll}
\hline No & Kualitas Tidur & F & P (\%) \\
\hline 1 & Baik & 12 & 19,0 \\
2 & Buruk & 51 & 81,0 \\
\hline & Jumlah & $\mathbf{6 3}$ & $\mathbf{1 0 0}$ \\
\hline
\end{tabular}

Sumber : Data Sekunder, 2020

Berdasarkan tabel 4.2 diatas didapatkan hasil data menurut kualitas tidur lanjut usia ditemukan sebagian besar lansia memiliki kualitas tidur yang buruk atau kurang baik (68.3\%). Hal ini karena pada masa lanjut usia mengalami penurunan tahap III dan tahap IV pada tidur NREM Stockslager dalam Setyowati (2015).

\section{PEMBAHASAN}

\section{Gambaran Kualitas Tidur Lansia berdasarkan Usia}

Berdasarkan hasil penelitian didapatkan responden dengan usia lansia yang memenuhi kriteria inklusi untuk menjadi responden dalam penelitian ini yaitu sebanyak 63 orang, dengan penggolongan umur sesuai dengan pembagian umur lansia menurut WHO. Usia antara 60-74 tahun sebanyak 18 lansia $(28,6 \%)$, pada rentang usia 75-90 tahun didapatkan hasil yaitu lansia sebanyak 45 lansia $(71,4 \%)$. Dari keseluruhan responden, ditemukan bahwa tidak seorangpun lansia yang menjadi responden berusia 90 tahun keatas.

Peningkatan usia yang dialami seseorang dan proses penuaan yang terjadi berdampak terhadap terjadinya perubahan pada pola tidur. Perubahan yang terjadi diantaranya terjadi 
kemajuan pada fase sirkadian, penurunan tidur gelombang lambat, pengurangan secara absolut tidur REM, peningkatan pada stadium 1, dan pengurangan pada durasi tidur NREM tahap 3 dan 4, yang mana merupakan fase tidur yang paling dalam (Wolkove dkk, 2007).

Hasil penelitian yang dilaporkan oleh Dağlar (2012) yang dilakukan di Turki mendapatkan data yaitu pada seluruh responden lansia yang berusia 65 tahun ke atas $(\mathrm{N}=112)$ baik yang tinggal di rumah maupun yang berada di rumah perawatan khusus lansia memiliki prevalensi lebih dari 50\% mengalami kualitas tidur yang buruk (63.3\% dan 55.8\%, secara berurutan). Hal ini sesuai dengan penelitian lain yang menemukan bahwa prevalensi kualitas tidur buruk pada lansia akan meningkat seiring dengan peningkatan usia, dengan hasil penelitiannya didapatkan data yaitu $32.1 \%(95 \% \mathrm{CI}=$ 27.8-36.4\%) ditemukan pada usia antara 60-69 tahun dan meningkat menjadi $52.5 \%$ (95\% CI $=45.9-59.1 \%)$ pada lansia usia 80 tahun ke atas (Luo dkk, 2013).

Penelitian lain melaporkan sekitar $60.9 \%$ dari responden $(\mathrm{N}=992)$ dinyatakan memiliki kualitas tidur yang buruk, dengan rata-rata usia responden 75.49 ( $\mathrm{SD}=6.56$ tahun). Namun pada penelitian tersebut disebutkan bahwa tidak ada perbedaan yang signifikan secara statistik pada nilai rerata skor PSQI ( $p>0.05$ ) diantara kelompok umur (Eser dkk, 2007).

\section{Gambaran Kualitas Tidur Lansia berdasarkan Jenis Kelamin}

Pada penelitian ini didapatkan data bahwa sekitar 47,6\% (N=30) lansia yang berjenis kelamin laki-laki dan
$52,4 \% \quad(\mathrm{~N}=33) \quad$ lansia perempuan dinyatakan memiliki kualitas tidur yang buruk. Tingginya angka prevalensi kualitas tidur yang buruk sesuai dengan kajian pustaka yaitu akibat terjadi perubahan sex hormone pada lansia terutama pada lansia yang berjenis kelamin perempuan akibat berlangsungnya proses menopause. Disebutkan pula pada fase transisi menuju menopause dan fase post menopausal cenderung terkait dengan perubahan fisik dan psikologis yang dapat meningkatkan insiden munculnya gangguan seperti nocturnal hot flashes, gangguan mood dan gangguan pernapasan saat tidur yang dapat mengurangi kualitas tidur (Tranah dkk, 2010; Madrid-Valero dkk, 2016).

Berdasarkan Stages of Reproductive Aging Workshop 2011, status menopause dibagi menjadi empat fase yaitu early Menopausal Transition (early MT), late Menopausal Transition (late MT), early Post Menopausal (early PM) dan late Post Menopausal (late PM). Diantara keempat fase menopause tersebut, wanita yang berada pada fase early PM ditemukan mengalami gejala menopause yang paling tinggi, kemudian diikuti oleh wanita pada fase late PM, late MT dan early MT. Hal tersebut berdampak terhadap perbandingan skor PSQI yang signifikan pada masing-masing fase menopause. Wanita yang berada pada fase early MT ditemukan memiliki skor PSQI yang paling rendah, yang mana hal tersebut mengindikasikan kualitas tidur yang baik. Kemudian diikuti oleh fase late MT yang masih terkait dengan kualitas tidur yang baik. Skor PSQI tertinggi ditemukan pada wanita yang berada pada fase early PM dan late PM, yang menunjukkan pada fase tersebut 
kebanyakan wanita memiliki kualitas tidur yang buruk. (Zhang dkk, 2016).

Pada penelitian yang dilakukan oleh Eser dkk (2007) ditemukan bahwa perempuan secara signifikan memiliki rerata skor PSQI yang lebih tinggi daripada responden laki-laki $(\mathrm{p}<0.05)$. Hasil penelitian yang serupa dilaporkan oleh Luo dkk (2013) yaitu prevalensi lansia berjenis kelamin perempuan yang memiliki kualitas tidur buruk sekitar $45.8 \%$ (95\% CI =41.9-49.7\%), yang secara signifikan lebih tinggi daripada laki-laki $\quad(35.8 \%, 95 \%$ CI $=31.4-40.1 \%$ ). Penelitian yang dilakukan di Taiwan oleh Chueh dkk (2009) melaporkan dari 25,163 wanita Taiwan asli yang menjadi responden didapatkan sekitar 20.54\% memiliki kualitas tidur yang buruk.

Hal yang berbeda ditemukan oleh peneliti lain seperti Lemola dkk (2013) dalam penelitiannya menyebutkan bahwa wanita rata-rata memiliki total durasi tidur yang lebih lama (p,0.001), efisiensi tidur yang lebih tinggi ( $\mathrm{p}, 0.001$ ), dan onset latensi tidur yang lebih pendek ( $\mathrm{p}, 0.001)$ dibandingkan laki-laki. Yoon H-S dkk (2015) dalam penelitiannya terhadap orang dewasa dan lansia di Korea dengan jumlah responden 84,094 (27,717 laki-laki and 56,377 perempuan) melaporkan bahwa sekitar $65 \%$ laki-laki dan $60 \%$ perempuan memiliki durasi tidur yang normal (6-7 jam).

\section{Gambaran Kualitas Tidur Lansia berdasarkan Status Perkawinan}

Berdasarkan penelitian, lansia yang menjadi responden didominasi oleh lansia yang berstatus janda/duda $81,0 \%$ $(\mathrm{N}=51)$, dibandingkan dengan lansia dengan berstatus menikah $19,0 \%$ $(\mathrm{N}=12)$.
Penelitian oleh Eser dkk (2007) menyebutkan skor rata-rata PSQI lansia yang berada dalam status menikah secara signifikan lebih rendah daripada lansia yang berada diluar status pernikahan $(\mathrm{p}<0.05)$. Dalam hal ini, kualitas tidur yang dimiliki oleh lansia berstatus menikah dipengaruhi oleh dukungan sosial yang diberikan oleh pasangannya yang mana dapat membantu mengatasi stress psikologis yang mungkin terjadi. Hal yang sama juga disebutkan dalam penelitian Luo dkk (2013) bahwa lansia yang memiliki kualitas tidur yang buruk umumnya tinggal sendiri tanpa pasangannya $(14.4 \%, \mathrm{p}, 0.001)$.

Data tersebut sesuai dengan Teori Lueckenotte dalam Wahyuni dkk (2009) yang menyebutkan bahwa seseorang yang tinggal sendiri atau telah kehilangan suami/istri cenderung memiliki kondisi psikologis yang tidak nyaman sehingga dapat mengganggu pola tidurnya. Hal ini dihubungkan dengan adanya perasaan ganjil dalam memulai tidur tanpa pasangannya yang dapat memicu timbulnya stress emosional.

Perbedaan hasil yang didapatkan pada penelitian ini dapat disebabkan oleh proporsi responden yang didominasi oleh lansia dengan status menikah, sehingga tidak dapat terlihat dengan jelas perbandingan kualitas tidur dengan status pernikahan yang lainnya. Hal yang berbeda dilaporkan oleh peneliti lain yaitu rerata skor PSQI yang ditemukan pada kelompok lansia dengan status menikah secara signifikan lebih tinggi (11.0 2.5$)$ dibandingkan dengan lansia yang berstatus lajang atau janda/duda ataupun bercerai $(\mathrm{p}<0.05)$. (Orhan $\mathrm{dkk}$, 2011). 


\section{Kualitas tidur selama pandemi} covid-19 pada lansia di PSTW Nirwana Puri Samarinda

Hasil sebaran data penelitian kualitas tidur pada lansia di PSTW Nirwana Puri Samarinda itu didapatkan skor rata-rata adalah 8. Berdasarkan hasil penelitian yang telah dilakukan bahwa terdapat data bahwa $51(81,0 \%)$ dari lansia yang menjadi responden memiliki kualitas tidur yang buruk dan $12(19,0 \%)$ lansia lainnya mengalami kualitas tidur yang baik., terdapat dua komponen kualitas tidur yang terganggu, yaitu komponen gangguan tidur dan disfungsi siang hari yang dapat disebabkan oleh berbagai faktor. Perlunya kesadaran untuk memenuhi kualitas tidur lansia karena merupakan kondisi yang penting bagi kesehatan. Aktivitas sehari-hari perlu pembatasan sehingga dapat meningkatkan kualitas tidur yang baik pada lansia. Jika kualitas tidur yang baik maka tubuh akan sehat dan bersemangat untuk beraktivitas sehari-hari.

Menurut Hidayat (2006) Kualitas tidur adalah kepuasan seseorang terhadap tidur, sehingga seseorang tersebut tidak memperlihatkan perasaan lesu, lelah dan apatis, kehitaman disekitar mata, kelopak mata bengkak, konjungtiva merah, mata perih, perhatian terpecah-pecah, sakit kepala dan sering menguap atau mengantuk, dan beberapa faktor yang mempengaruhi kualitas tidur seperti penyakit, lingkungan, kelelahan, gaya hidup, stress emosional, motivasi, dan nutrisi yang banyak dialami oleh lansia.

Menurut Lund et al (2010) mengatakan bahwa kualitas tidur lansia yang buruk mempengaruhi mood (kemarahan, kebingungan, depresi, kelelahan, dan tekanan darah). Dengan demikian, pada lansia di PSTW Nirwana Puri Samarinda dapat mendapat manfaat yang maksimal dan memiliki performa yang baik apabila kebutuhan akan tidur yang berkualitas terpenuhi dengan baik.

Dari hasil penelitian yang didapatkan komponen gangguan tidur terganggu, secara signifikan kebutuhan tidur yang tidak tercukupi akan menyebabkan penurunan fungsi kognitif, ingatan jangka pendek, dan juga merusak konsentrasi yang tentunya akan menghambat proses pembelajarn yang sedang dijalani (Gunanthi, 2016).

Luo dkk (2013) melaporkan berdasarkan penelitian yang dilakukan di China, diperoleh hasil sekitar 41.5\% lansia dinyatakan memiliki kualitas tidur yang buruk. Data yang dilaporkan oleh Wahyuni dkk (2009) juga 
mendukung temuan hasil penelitian yaitu pada penelitiannya diperoleh data sekitar 55\% dari responden memilki kualitas tidur yang buruk dan 45\% responden lainnya dinyatakan memiliki kualitas tidur baik. Kualitas tidur baik yang dimiliki sejumlah lansia disadari penulis sesuai dengan tinjauan pustaka yaitu sebagai akibat dari adanya kemampuan adaptasi yang baik terhadap perubahan fisik serta psikososial sehingga tidak memberikan pengaruh yang besar terhadap pola tidur (Wahyuni dkk, 2009).

Hasil penelitian ini diperkuat dengan pernyataan Stockslager dalam Setyowati (2015). Stockslager mengatakan terjadi penurunan tahap III dan tahap IV pada tidur NREM lanjut usia selain itu efisiensi tidur juga berkurang seiring bertambahnya usia. Hasil penelitian ini sejalan dengan pernyataan Ghaddafi dalam Rahmah, Retnaningsih, \& Apriana (2018). Menurut pernyataan yang Ghaddafi kemukakan pada masa usia lanjut terjadi berbagai macam perubahan dan kemuduran. Perubahan kualitas tidur merupakan salah satu perubahan yang terjadi pada masa usia lanjut. Perubahan kualitas tidur ini sering membuat waktu tidur lanjut usia berkurang.
Hasil penelitian ini sependapat dengan hasil penelitian yang dilakukan oleh Vilasinee Ari Hara Kumar, Nyoman Ratep (2017) dengan judul Kualitas Tidur Pada Geriatri di Panti Jompo Tresna Wana Seraya Denpasar Bali. Pada penelitian ini didapatkan bahwa kualitas tidur lanjut usia sebagian besar berada pada kualitas tidur buruk. Dari 30 orang lanjut usia didapatkan 19 orang lanjut usia $(63,3 \%)$ mengalami kualitas tidur yang buruk sedangkan 11 orang lanjut usia $(36,7 \%)$ memiliki kualitas tidur yang baik.

Hasil penelitian ini memiliki kesamaan juga dengan hasil penelitian yang dilakukan oleh Ni Kadek Risa Astria dengan judul gambaran kualitas tidur pada lansia di desa adat pecatu, kecamatan kuta selatan, kabupaten badung tahun 2016. Berdasarkan hasil penelitian, kualitas tidur lansia lebih baik ditemukan pada rentang usia 6074 tahun (23.1\%) dibandingkan dengan usia 75-89 tahun (14.3\%). Lansia berjenis kelamin perempuan (26.9\%) memiliki kualitas tidur yang lebih baik dibandingkan dengan laki-laki (15\%). Kualitas tidur pada lansia dengan status janda/duda (33.3\%) lebih baik dibandingkan dengan status menikah (20\%). Perhatian dan penanggulangan secara komprehensif meliputi fisik, 
psikologis serta lingkungan dari keluarga serta pemerintah setempat sangat diharapkan untuk dapat meningkatkan kualitas tidur lansia.

\section{REFERENSI}

Alligood. M. R. 2014. Pakar teori keperawatan. Edisi Indonesia ke-8 volume 2. Singapore: Elsevier

Aspiani, Reny Yuli (2014). Buku Ajar Asuhan Keperawatan Gerontik Aplikasi Nanda, NIC dan NOC Jilid 2. Jakarta : TIM

Azizah, Lilik M. 2011. Keperawatan Lanjut Usia. Yogyakarta: Graha Ilmu.

Cheri,Eric ( 2018 ).Poor sleep quality and insufficient sleep of collegiate student-athlete population. Journal of the national sleep foundation : Sleep Healt

C. C. Lai, T. P. Shih, W. C. Ko, H. J. Tang, and P. R. 2020. Hsueh, "Severe acute respiratory syndrome coronavirus 2 (SARS-CoV-2) and coronavirus disease-2019 (COVID19): The epidemic and the challenges," Int. J. Antimicrob. Agents, vol. 55, no. 3, p. 105924.

Dahlan, M.S (2011). Metodologi Penlitian Keperawatan). Jakarta : Salemba Medika

Dariah, Elis Deti; Okatiranti. (2013). Hubungan Kecemasan Dengan Kualitas Tidur Lansia di Posbindu
Anyelir Kecamatan Cisarua

Kabupaten Bandung Barat. Jurnal Ilmu Keperawatan Universitas BSI Bandung, September 2015, Volume III, No. 2.

Departemen Kesehatan RI. (2013) Populasi Lansia Diperkirakan Terus Meningkat.http://www.depkes.go.id /article/view/13110002/populasilan siadiperkiraan-terus-meningkathingga-tahun202.html (Diakses tanggal 19 Oktober 2015).

Destiana Agustin (2012), dengan judul Faktor-Faktor yang Mempengaruhi Kualitas Tidur pada Pekerja Shift di PT Krakatau Tirta Industri Cilegon, Depok: Fakultas Universitas Indonesia Ilmu Keperawatan.

Dinas Kesehatan Kota Samarinda (2017). Jumlaih Lansia Kota Samarinda. Kota Samarinda

Ernawati, (2018). Gambaran Kualitas tidur dan gangguan tidur pada lansia dip anti sosial Tresna Werdha Budi Luhur Kota Jambi . Jurnal Keperawatan: Jurusan Keperawatan Poltekes Kemenkes Jambi

Habibillah \& Bahri (2016), dengan judul Faktor-Faktor Yang Mempengaruhi Kualitas Tidur Pada Pasien Asma Di Rsud Dr. Zainoel Abidin Banda Aceh. 
Hidayat ,A.Aziz Alimul (2014). Metode Penelitian Keperawatan dan Teknik Analisa Data .Jakarta:Salemba Medika

Kaplan, H. I., Sadock, B. J., Grebb, J. A. 2010. Sinopsis Psikiatri (Widjaja Kusuma, Pentj). Jilid Dua. Binarupa Aksara.

Khasanah, K \& Hidayati, W (2012). Kualitas Tidur lansia di Balai Rehabilitasi Sosial" Mandiri" Semarang. Diaskes pada 17 Agustus 2018 dari http://ejournalS1.undip.ac.id.index.php/jnursing/a rticle/view/449/448

King LA. Psikologi umum : sebuah pandangan apresiatif. Jakarta : Salemba Medika, 2010

Maas, L. Meridean. 2011. Asuhan Keperawatan Geriatrik: Diagnosis NANDA, Kriteria Hasil NOC, \& Intervensi NIC. Jakarta: EGC.

Magfirah, Inun. (2016). Hubungan Kualitas Tidur dengan Tekanan Darah pada Mahasiswi Program Studi S1 Fisioterapi Angkatan 2013 dan 2014 di Universitas Hasanuddin. Makassar : Program Studi Fisioterapi Fakultas Kedokteran Universitas Hassanudin. Notoatmodjo, Soekidjo. (2012). Metodologi Penelitian Kesehatan. Jakarta : Rineka Cipta.
Potter \& Perry. 2010. Fundamental of Nursing Atau Fundamental Keperawatan. Jakarta: Salemba Medika.

Raveena,

AZ. 2017. https://www.dictio.id/t/perubahanfisiologis-apa-saja-yang-terjadiakibat-proses-penuaan/6104

Rina Mariani (2016), dengan judul Faktor-Faktor Yang Mempengaruhi Pola Tidur Pada Anak Yang Menjalani Hospitalisasi Di Ruang Rawat Inap Anak Rsd. Mayjend. Hm. Ryacudu Kotabumi Tahun 2016.

Safrizal, Putra DI, Sofyan S \& Bimo. 2020. Pedoman Umum Menghadapi Pandemi Covid-19 Bagi Pemerintah Daerah Pencegahan, Pengendalian, Diagnosis Dan Manajemen. Tim Kerja Kementrian Dalam Negeri.

Saputra,Lydon(2013).Pengantar

Kebutuhan Dasar Manusia.

Tanggerang: Binarupa Aksara Publiser.

Saryono. (2011). Kumpulan Instrumen Penelitian Kesehatan. Bantul : Nuhamedika.

Setiadi. (2013). Konsep dan Penulisan Riset Keperawatan. Yogyakarta : Graha Ilmu.

Silvanasari , Angelia Irwana. (2012). Faktor- Faktor yang Brhubungan 
dengan Kualitas Tidur yang buruk pada Lansia di Wilayah Wonojati Kecamatan Jenggawah Kabupaten Jember . Jurnal Keperawatan : Program Studi Ilmu Keperawatan Universitas Jember.

Sugiyono. 2012. Metode Penelitian Kuantitatif Kualitatif Dan $R \& D$. Bandung: Alfabeta

Sugiyono. 2013. Metode Penelitian Pendidikan Pendekatan Kuantitatif, Kualitatif Dan R\&D. Bandung: Alfabeta

Sugiyono. 2016. Metode Penelitian Kuantitatif, Kualitatif dan $R \& D$. Bandung: Alfabeta.

Sumirta, I Nengah \& Laraswati, AA Istri. (2014). Faktor yang Menyebabkan Gangguan Tidur (Insomnia) Pada Lansia. Jurnal Keperawatan : Jurusan Keperawatan Politeknik Kesehatan Denpasar.

Sunaryo (2016 ). Asuhan Keperwatan Gerontik.Yogyakarta : Cv.Andi

World Health Organization (2015) Ageing and Health. http://www.who.int/mediacentre/fa ctsheets/fs404/en/ (Diakses 7 November 2015). 